\title{
GRAHAM HADLEY
}

Professor Graham Hadley, Associate Professor in Forest Mensuration at the University of New Brunswick, was lost in the same tragic drowning on Thanksgiving Day.

Professor Hadley was a graduate in Forestry of Toronto University of the class of 1941. He was a first class student leading his class during his last two years. As a student he worked during the summer months with the Spruce Falls Power and Paper Company.

Soon after graduating he went into the Canadian army and served overseas with the intelligence corps being discharged with the rank of captain.

Following his discharge from the army he was employed professionally with the Spruce Falls Power and Paper Company at Kapuskasing, Ontario, until joining the faculty of U.N.B. in 1946.

He was extremely interested in his work in statistics and mensuration and was an excellent teacher, being very conscientious and having his work both in the classroom and in the field very well organized.

He was always ready to help a student who needed additional instruction and set high standards both for himself and for his students.

During the summer months he was employed by both the Spruce Falls Power and Paper Company and Fraser Companies Ltd., and his work was very highly regarded by both these companies.

Professor Hadley was greatly interested in, and took an active part in all C.I.F. meetings in the Maritimes, and his loss extends far beyond university circles.

Professor Hadley was very much wrapped up in his family and leaves his widow and three small sons.

\section{EMPLOYMENT SERVICE}

A new service has been established in Canada for foresters and people employing foresters. The service is an agency or employment bureau which will establish contact between graduate foresters wishing employment and people wishing to hire graduate foresters. In each issue of the Forestry Chronicle space will be allotted to this agency and in two columns titled "Positions Available" and "Positions Wanted", succinct advertisements will show the qualifications of those wishing employment and the opportunities for employment available. Each advertiser, if he wishes to remain anonymous, will be given a number, and a record of his request will be filed at the central agency.

An up-to-date list of applicants and opportunities will be kept, and this list will consist of the names of those who wish positions and those who wish to hire graduates. Anyone wishing information before the list is published in the Chronicle, may obtain it by writing to the agency. The agency would not recommend personnel for positions, but would direct applicants to work in which they have indicated interest. No advertisements would appear in the Chronicle unless those concerned have given their permission. There will be no charge for this service.

At the present time the agency will be directed by the undersigned with the guidance of the executive, and all correspondence should be sent to him in care of the Dominion Laboratory of Forest Biology, 144 Front Street West, Toronto 1, Ontario. 